\title{
Characterization of a rediscovered haplosporidian parasite from cultured Penaeus vannamei
}

\author{
Linda M. Nunan ${ }^{1, *}$, Donald V. Lightner ${ }^{1}$, Carlos R. Pantoja ${ }^{1}$, Nancy A. Stokes ${ }^{2}$, \\ Kimberly S. Reece ${ }^{2}$ \\ ${ }^{1}$ Department of Veterinary Science and Microbiology, University of Arizona, Tucson, Arizona 85721, USA \\ ${ }^{2}$ School of Marine Science, Virginia Institute of Marine Science, College of William and Mary, Gloucester Point, \\ Virginia 23062, USA
}

\begin{abstract}
Mortalities of Penaeus vannamei, cultured in ponds in Belize, Central America, began during the last part of the grow-out cycle during the cold weather months from September 2004 through February 2005. Tissue squashes of infected hepatopancreata and histological examination of infected shrimp revealed that the mortalities might have been caused by an endoparasite. To confirm the diagnosis, DNA was extracted from ethanol preserved hepatopancreata and the small-subunit rRNA gene was sequenced. The $1838 \mathrm{bp}$ sequence was novel and phylogenetic analysis placed the $P$. vannamei parasite within the phylum Haplosporidia as a sister taxon to a clade that includes Bonamia and Minchinia species. In situ hybridization was performed using anti-sense DNA probes that were designed to hybridize specifically with the parasite's nucleic acid. This organism presents similar characteristics to those of a haplosporidian that infected cultured $P$. vannamei imported from Nicaragua into Cuba, as described by Dyková et al. (1988; Fish Dis 11:15-22).
\end{abstract}

KEY WORDS: Haplosporidian · Shrimp · Parasite $\cdot$ Molecular phylogenetic analysis Resale or republication not permitted without written consent of the publisher

\section{INTRODUCTION}

During the 2004 to 2005 winter stocking season, mortalities of cultured Penaeus vannamei occurred in several grow-out ponds in Belize, Central America. Salinity in the affected ponds ranged from 28 to 33 ppt. The shrimp exhibited reduced feed consumption that led to a reduced growth rate. Infected shrimp had flaccid bodies with red tails, and displayed melanization and atrophy of the hepatopancreatic (HP) tubules. Tissue squashes and histological examination revealed severe infection of the HP epithelial cells and low lipid levels in the tubules, caused by presumed haplosporidian parasites.

The Haplosporidia comprise a small taxon of endoparasites of which 36 recognized species have been reported (Burreson \& Ford 2004). These parasites are generally associated with marine invertebrates, although Haplosporidium pickfordi is a known parasite of a freshwater snail (Barrow 1961, Burreson 2001).
Many species cause disease in commercially important wild and cultured mollusks worldwide, including many species of oysters (Andrews et al. 1962, Andrews 1966, Bonami et al. 1985, Hine et al. 2001), clams (Armstrong \& Armstrong 1974, Novoa et al. 2004) and abalone (Diggles et al. 2002, Reece \& Stokes 2003).

Haplosporidian and haplosporidian-like parasites have also been reported infecting crustaceans. Several species of mud crabs (Panopeus herbstii, Eurypanopeus depressus, and Rhithropanopeus harrisii) have been found infected with the parasites (Rosenfield et al. 1969, Perkins 1975). In addition, 3 species of shrimp - the spot prawn Pandalus borealis, the pink shrimp P. platyceros (Meyers et al. 1994, Bower \& Meyer 2002), and the commercially important, cultured Pacific white shrimp Penaeus vannamei (Dyková et al. 1988), have been documented with infections attributed to haplosporidian-like parasites. Molecular analysis was used to place the spot prawn parasite within the Haplosporidia, but taxonomic affiliation remains 
unresolved due to lack of morphological features (Reece et al. 2000). Dyková et al. (1988) reported a putative haplosporidian infecting cultured $P$. vannamei imported from Nicaragua into Cuba. The authors described the presence of haplosporosomes, but mature spores were not observed and, at that time, molecular analysis was not possible. This paper presents histological and molecular characterization of a putative haplosporidian, perhaps the same organism described by Dyková et al. (1988), that has possibly re-emerged as a pathogen in $P$. vannamei cultured in Belize, Central America.

\section{MATERIALS AND METHODS}

Pathogen identification. Samples of Penaeus vannamei from shrimp farm ponds in Belize that displayed slow growth and reduced survival were preserved by several methods. Infected hepatopancreata (HPs) were immersed in $10 \%$ formalin in seawater for later use in unstained tissue squash preparations. Davidson's AFA fixative (Bell \& Lightner 1988) was used for preservation of affected cephalothoraces for histological examination and in situ hybridization assays. PCR assays were conducted using DNA extracted from HPs preserved in $70 \%$ ethanol.

Tissue squash preparations. Small samples of formalin preserved HP tubules were excised, placed on a microscope slide in a drop of tap water, cover slipped and then squashed with gentle pressure before viewing by reduced light bright-field microscopy.

Histological examination and in situ hybridization assays. The cephalothoraces of specimens preserved in Davidson's fixative were dissected along the midsagittal plane, processed through a graded ethanol series, cleared, embedded in Paraplast Plus paraffin (Fisher Scientific), sectioned (4 $\mu \mathrm{m})$, and mounted on microscope slides. The sections were deparaffinized and stained with Mayer-Bennett's hematoxylin/eosinphloxine (H\&E). Sections from selected specimens were subjected to acid-fast staining technique (Lightner 1996) to look for the presence of spores. Sections were also mounted onto positively charged microscope slides that were used for in situ hybridization assays. Histological terminology used in this study follows that of Bell \& Lightner (1988), and shrimp taxonomy is in accordance with Holthuis (1980).

DNA extraction and amplification of the small subunit (SSU) ribosomal RNA (rRNA). DNA was extracted from $50 \mathrm{mg}$ of infected HPs tissues using the High Pure PCR Template Preparation Kit (Roche Diagnostics), following the manufacturer's protocol; $350 \mathrm{ng}$ of the extracted DNA was used as the PCR template and was amplified using 'universal' eukaryotic primers that tar- get the SSU rRNA gene (Medlin et al. 1988). The PCR cycling parameters described by Medlin et al. (1988) were followed. The $1838 \mathrm{bp}$ PCR amplified product was run on a $0.8 \%$ agarose gel in TBE buffer (trisborate-EDTA) with ethidium bromide $\left(0.5 \mu \mathrm{g} \mathrm{ml} \mathrm{m}^{-1}\right)$ incorporated into the gel (Maniatis et al. 1982).

Sequencing of PCR product and subsequent cloning of amplified product. The amplicon from the PCR reaction was eluted using the QIAquick PCR Purification Kit (Qiagen), following the manufacturer's protocol. To determine the DNA concentration, a BioPhotometer (Eppendorf) at $260 \mathrm{~nm}$ was used. The $1838 \mathrm{bp}$-long PCR product was sequenced at the University of Arizona Research Laboratory DNA sequencing facility. Following alignment of the forward and reverse sequences, a GenBank search was performed. The eluted PCR amplicon was also used for cloning. The fragment was ligated with T4 DNA ligase into the EcoRV site of the pGEM-T Easy Vector System II (Promega Corporation) and subsequently transformed into JM109 competent cells. Following transformation, the cells were spread onto LB-amp plates, pretreated with Xgal (5-bromo-4-chloro-3-indoyl- $\beta$-D-galactoside) and IPTG (isopropyl-1-thio- $\beta$-D-galactoside) (Maniatis et al. 1982). The plates were incubated overnight at $37^{\circ} \mathrm{C}$, and the next day the white colonies were selected and grown overnight (with shaking) in $5 \mathrm{ml}$ LB-amp broth at $37^{\circ} \mathrm{C}$. The cultures were prescreened by directly pipetting $1 \mu \mathrm{l}$ of the broth into the PCR reaction mixture containing the 'universal' SSU rRNA primers and amplified according to the PCR protocol of Medlin et al. (1988). The PCR amplicons were analyzed by electophoresis and the clones that generated the $1838 \mathrm{bp}$ fragment were selected. The cloned DNA was sequenced at the University of Arizona Research Laboratory DNA sequencing facility and the aligned sequence was compared to the original sequence from the PCR product and compared to other eukaryotic nucleotide sequences in GenBank.

Phylogenetic analysis. The SSU rRNA gene sequences used in the phylogenetic analyses, along with their GenBank accession numbers and the accession number for the new undescribed Penaeus vannamei parasite, are listed in Table 1. Sequences were aligned using the CLUSTAL-W algorithm (Thompson et al. 1994) in the MacVector 8.0.2 (Accelrys, San Diego) package using a gap penalty of 8 for insertions and 3 for extensions both in pairwise and in multiple alignment phases. Pairwise genetic distances were calculated (uncorrected $\mathrm{p}$ values) and unweighted parsimony jackknife analysis was done using PAUP 4.0b10 (Swofford 2002) with 1000 replicates of 100 random additions and a deletion value of $30 \%$.

In situ hybridization (ISH) assays. Based on the SSU rRNA gene sequence from the undescribed candidate 
Penaeus vannamei parasite, anti-sense DNA probes were designed to hybridize specifically with the nucleic acid of this parasite. The probes were first tested for specificity against other available haplosporidian sequences using the MacVector software package. In addition, probe sequences were subjected to BLAST (Altschul et al. 1990) searches of GenBank. Secondary structure analysis of the RNA sequence was done using the MFOLD prediction of RNA structure program (Zuker et al. 1999; http://bioweb.pasteur.fr/ seqanal/interfaces/mfold-simple.html) to determine optimal binding sites (i.e. the loops) for the probe. Candidate DNA probes were commercially synthesized and 5' end-labeled with digoxigenin (Operon Biotechnologies). The successful probe was designated BeShHap450 (5'-TGCCCACCGCTTGTTTATC-3'). In situ hybridization assays were conducted as previously described (Stokes \& Burreson 1995, 2001) using 4 ng $\mathrm{Hl}^{-1}$ probe with tissue sections placed on positivelycharged slides (Fisher). Probe specificity was tested by performing ISH on tissue sections of shrimp infected with the haplosporidian parasites Haplosporidium nelsoni, Bonamia ostreae and Minchinia tapetis.

Table 1. Taxa included in phylogenetic analysis, with GenBank accession numbers (Acc. No.) of their small-subunit rRNA gene sequences. Belize, Central America P. vannamei parasite sequence is shown in boldface

\begin{tabular}{|ll|}
\hline Taxon & Acc. No. \\
\hline $\begin{array}{l}\text { Belize Central America Penaeus vannamei } \\
\text { parasite }\end{array}$ & DQ653412 \\
Bonamia perspora & \\
Bonamia ostreae & DQ356000 \\
Bonamia exitiosa & AF262995 \\
Bonamia roughleyi & AF337563 \\
Undescribed Crassostrea ariakensis Bonamia sp. & AY5542903 \\
Undescribed Ostrea chilensis Bonamia sp. & AY860060 \\
Minchinia teredinis & $\mathrm{U} 20319$ \\
Undescribed Cyrenoida floridana parasite & AY449712 \\
Minchinia chitonis & AY449711 \\
Minchinia tapetis & AY449710 \\
Haplosporidium lusitanicum & AY449713 \\
Haplosporidium pickfordi & AY452724 \\
Haplosporidium edule & DQ458793 \\
Haplosporidium armoricanum & AY781176 \\
Haplosporidium costale & AF387122 \\
Haplosporidium nelsoni & $\mathrm{U} 19538$ \\
Haplosporidium louisiana & $\mathrm{U} 47851$ \\
Urosporidium sp. & AY449714 \\
Urosporidium crescens & $\mathrm{U} 47852$ \\
Undescribed Haliotis iris parasite & AF492442 \\
Undescribed Pandalus platycerous parasite & AY449715 \\
Cercomonas longicauda & AF101052 \\
Heteromita globosa & $\mathrm{U} 42447$ \\
Chlorarachnion reptans. & $\mathrm{U} 03477$ \\
Gromia oviformis from Réunion & AJ457812 \\
Gromia oviformis from Guam & AJ457814 \\
\hline & \\
\hline
\end{tabular}

\section{RESULTS}

\section{Tissue squash preparations}

Squash preparations of $10 \%$ formalin preserved HPs from Penaeus vannamei presenting signs of disease showed heavily infected HP tubules. Generally, spherical membrane-bound plasmodia were visible at low magnification in the epithelial cells lining the HP tubules (Fig. 1a). In areas where the HP tubule was fractured and disrupted during the preparation of the tissue squash, free plasmodia were evident (Fig. 1b,d). Some plasmodia were considered to be in an early immature stage, with a single central nucleus (Fig. 1c). More developed plasmodia were also abundant in the squash preparations and these presented less readily apparent nuclei (Fig. 1d). Mature plasmodia were characterized as containing large numbers of small diameter $(\sim 1 \mu \mathrm{m})$, spherical, uninucleate trophonts, which were readily apparent in plasmodia that had ruptured (Fig. 1d).

\section{Histopathology}

Mid-sagittal histological sections from diseased $P e-$ naeus vannamei presented severe infections of the HPs. The infection in the HPs was determined to be caused by 2 agents: haplosporidian parasites and presumed Vibrio sp. Vibrio sp. were also seen infecting the midgut and anterior midgut caecum, in contrast to the haplosporidian, which was limited to the HPs. In the majority of the specimens examined, the percentage of affected HP tubules exceeded $50 \%$ of the section. In some specimens the area affected approached 80 to $90 \%$ of the section, with nearly all epithelial cells infected. Within infected cells, the multi-nucleated, spherical, membrane-bound plasmodia of the parasite were present in the cytoplasm, marginalizing but not compressing the nucleus. Most epithelial (B, R and F) cell types of the HP tubule (Bell \& Lightner 1988) were shown by histological examination to be infected (Fig. 2a,b). Multiple stages of development of the parasite were apparent in some sections, where early immature plasmodia could be identified by their relatively small size and content of amorphous cytoplasm (Fig. 2a). More common were more mature plasmodia, which were larger and contained numerous uninucleated or binucleated trophonts (Fig. 2). In some sections, fully mature plasmodia were observed releasing trophonts into the HP tubule lumen (Fig. 2d). In severely affected specimens, large numbers of released trophonts and some intact plasmodia were observed free in the HP tubule lumens, as well as in the lumen of the HP collecting ducts, anterior midgut and anterior midgut caecum (not shown). While foci of hemocyte-encapsulated and melanized HP tubules were present in some of the HPs 


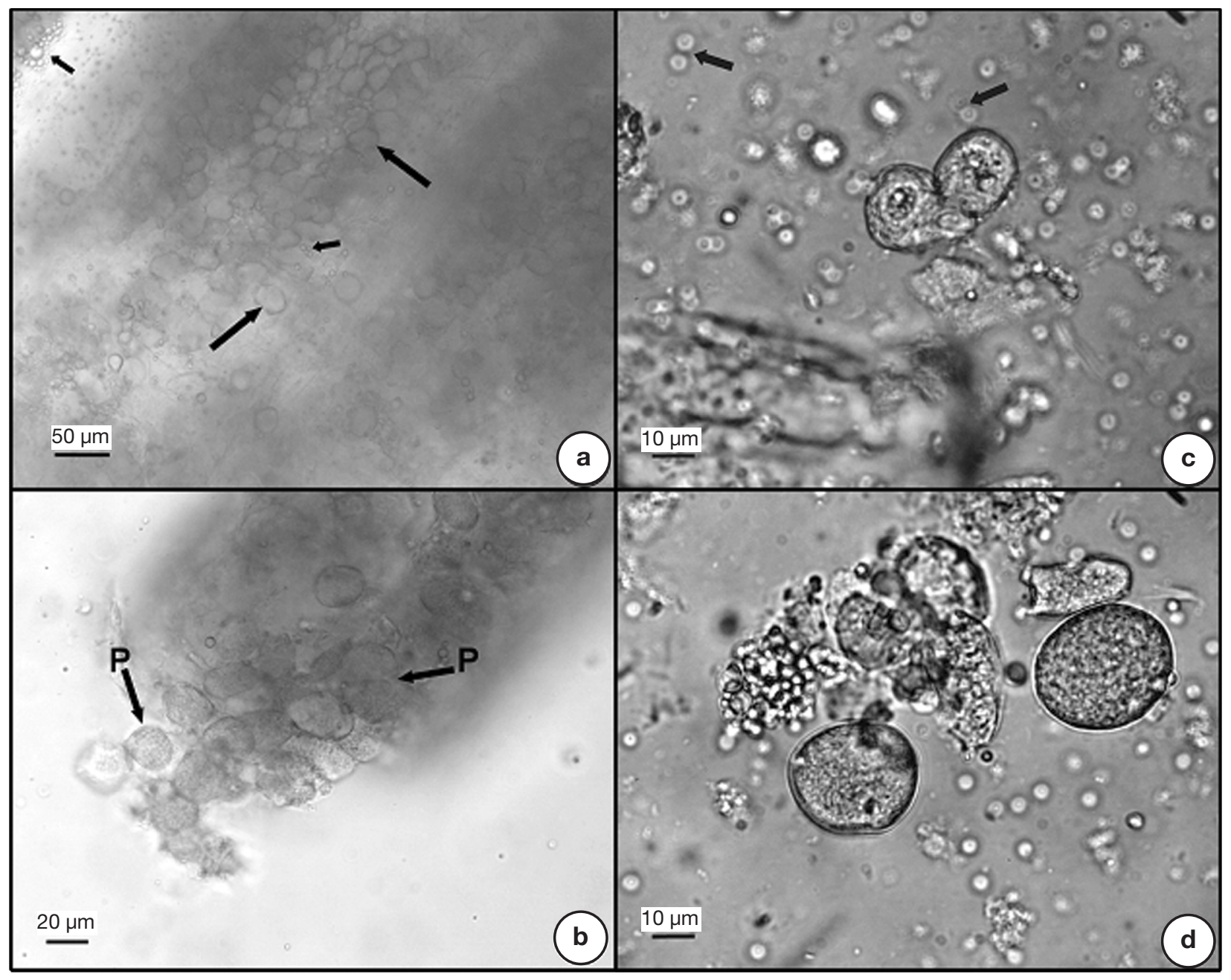

Fig. 1. Penaeus vannamei. Photomicrographs of unstained squashes of hepatopancreas (HP) from Pacific white shrimp, presenting a heavy infection by haplosporidian parasites. (a) Low magnification view of intact HP tubule: large generally spherical plasmodia (large arrows) of parasite are abundant in tubule. Lipid droplets (small arrows) released by mechanical disruption from HP tubule epithelial cells are also apparent. (b) Low magnification view of fragmented HP tubule; plasmodia (P) of parasite are abundant in what remains of HP tubule as well as some that were released by mechanical disruption from HP tubule epithelial cells. (c) High magnification view of 2 immature trophants that appear to be attached and that were released by mechanical disruption from HP tubule epithelial cells into surrounding water; trophant on left has a single central nuclei, while the plasmodium on the right is more developmentally advanced with several small nuclei apparent. Numerous single spherical trophonts (arrows) with central nucleus are also apparent. (d) High magnification view of several plasmodia in various stages of development ranging from immature (with developing trophont nuclei present but not clearly delineated) to mature plasmodium that has ruptured, releasing its content of spherical trophonts

examined (not shown), for the most part there was no host response to the parasite. The Ziehl-Neelsen method for demonstration of acid-fast bacteria and spores was applied to sections from selected specimens, but the results were negative.

\section{Sequence analysis and phylogenetics}

In pairwise genetic distance analyses, the Penaeus vannamei parasite SSU rRNA gene sequence was most similar to those of Bonamia ( $p=0.144$ to 0.162 ) and
Minchinia ( $p=0.159$ to 0.183 ) species. The pairwise genetic distances between the parasite sequence and those of Haplosporidium and Urosporidium species ranged from $\mathrm{p}=0.165$ to 0.274 ( $\mathrm{p}$-values for all of these pairwise comparisons, except with $H$. louisiana, were $<0.238$ ), while the distance to the outgroup sequences from the cercozoans and Gromia oviformis was generally higher ( $\mathrm{p}=0.247$ to 0.267 ).

Two equally parsimonious trees, 3887 steps in length, resulted from unweighted parsimony analysis. The $\mathrm{Pe}-$ naeus vannamei parasite was placed within the phylum Haplosporidia as a sister taxon to a clade that included 


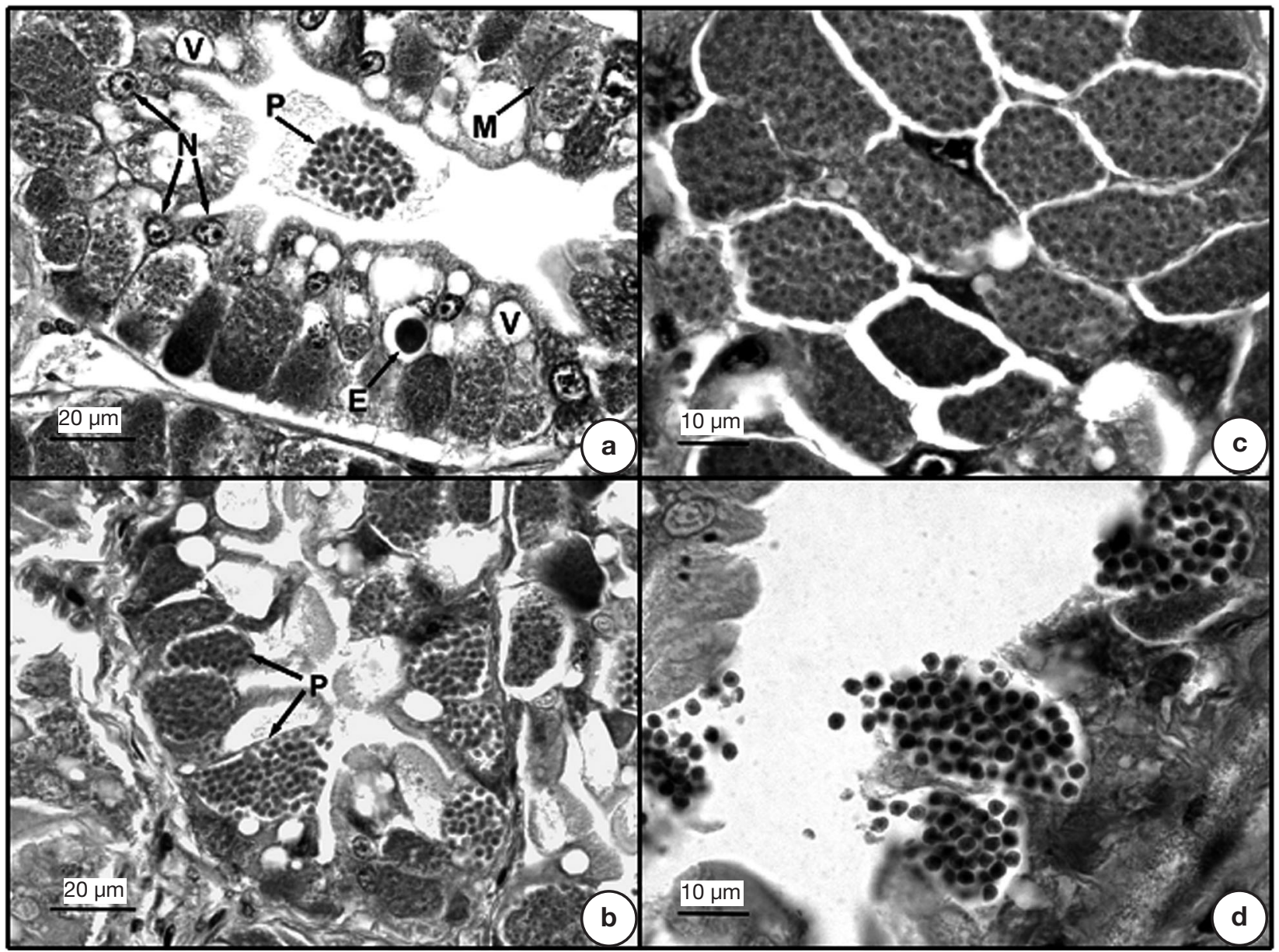

Fig. 2. Penaeus vannamei. Photomicrographs of histological sections of a Davidson's AFA-preserved hepatopancreas (HP) heavily infected by a haplosporidian parasite. Hematoxylin and eosin-phloxine (H\&E) stain. (a) Section through HP tubule with multi-nucleated plasmodia present in cytoplasm of nearly every tubule epithelial cell. The plasmodia range in development stage from early (E) with few nuclei of developing trophonts apparent, to mature (M) with large numbers trophonts clearly present within plasmodial limiting membrane. A still intact plasmodium (P), containing a large number of trophonts, has been sloughed from a cytolytic HP epithelial cell into tubule lumen. Signs of necrosis or inflammation of affected HP tubules are not evident despite severity of infection. HP tubule epithelial cell nuclei $(\mathrm{N})$ appear normal and some lipid or B-cell secretory versicles (V) are also present, indicating that infected cells have retained some of their function. (b) Section through HP tubule with mostly mature plasmodia present in cytoplasm of nearly every tubule epithelial cell; trophonts are readily apparent within most plasmodia (P), which are present in cytoplasm of HP tubule epithelial cells. (c) Higher magnification view of section of HP tubule, showing cytoplasmic plasmodia in a number of adjacent HP tubule epithelial cells; large numbers of trophonts are visible in each plasmodium. (d) Section through HP tubule showing cytolysis of several HP tubule epithelial cells, disruption of plasmodial membrane, and release of trophonts into tubule lumen

the Bonamia and Minchinia species, with a jackknife support value of $79 \%$ (Fig. 3). There was $99 \%$ jackknife support for inclusion of the $P$. vannamei parasite in a clade that contained the Bonamia and Minchinia species, and all Haplosporidium species except $H$. nelsoni and $H$. louisiana, while there was $100 \%$ jackknife support for a clade which included the $P$. vannamei parasite with all currently described Haplosporidium, Urosporidium, Minchinia and Bonamia species, as well as several undescribed species presumed to be in the phylum Haplosporidia (Burreson et al. 2004, Reece et al. 2004). Paraphyly of the genus Haplosporidium was observed in this analysis and was also demonstrated in previous studies (Reece et al. 2004, Burreson \& Reece 2006), although monophyletic Urosporidium, Minchinia and Bonamia clades were found, assuming that the currently undescribed species that fall within each of these clades are placed with their respective genera when they are described and the full species designations are given. The $P$. vannamei parasite did not fall within any of these clades, nor within the clade containing most Haplosporidium species. 


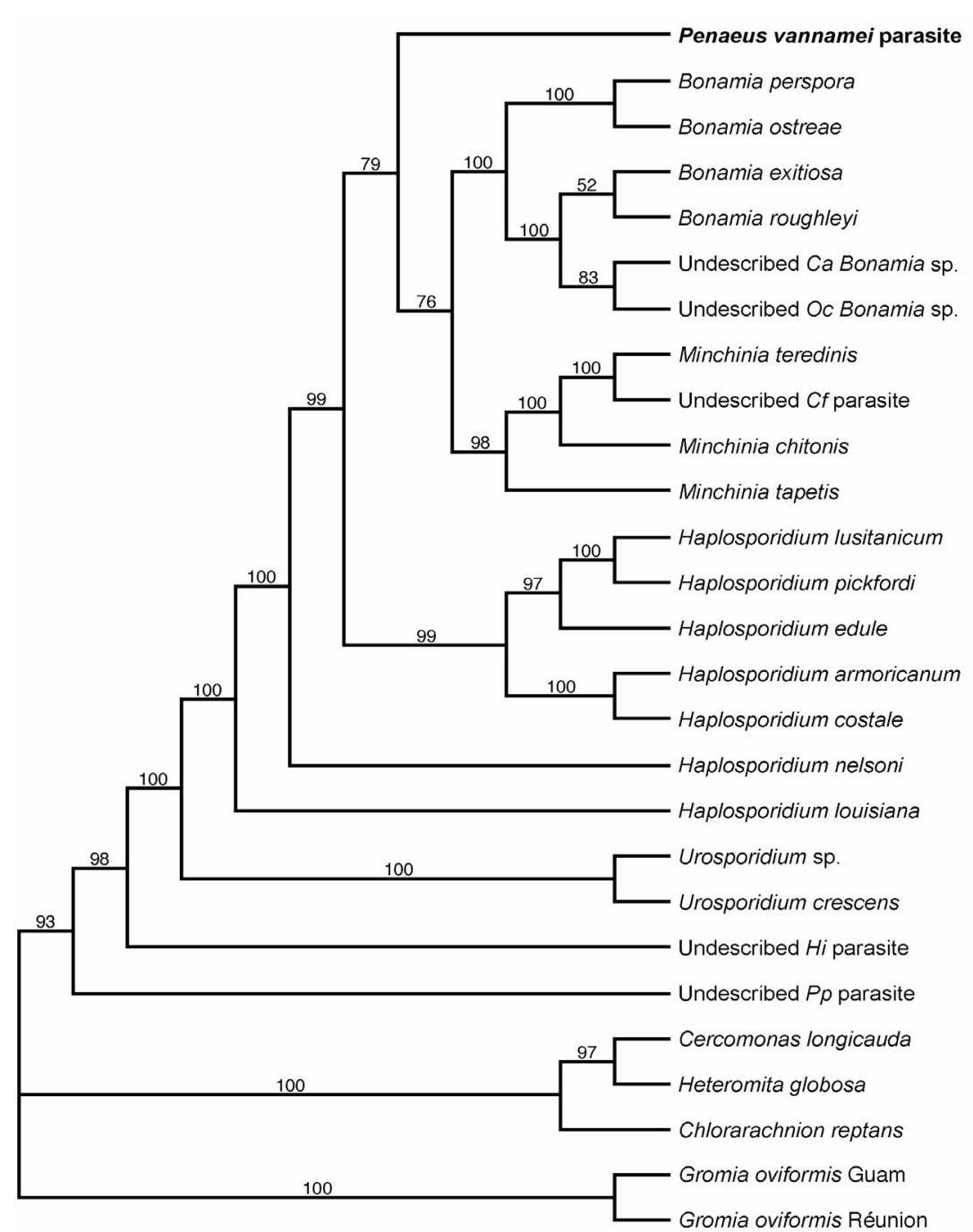

Fig. 3. Parsimony jackknife tree resulting from analysis of SSU rRNA gene sequences from Penaeus vannamei parasite (bold), haplosporidians, cercozoans and Gromia oviformis. Jackknife support values for each clade are given when $>50 \%$. Tree was rooted with cercozoan and G. oviformis sequences. Ca: Crassostrea ariakensis; Cf: Cyrenoida floridana; Hi: Haliotis iris; Oc: Ostrea chilensis; Pp: Pandalus platycerous

\section{In situ hybridization assays}

Only 1 of the candidate probes was specific for the shrimp haplosporidian: Probe BeShHap450 hybridized strongly with the parasite in Penaeus vannamei, but not with the host nor with the haplosporidians Haplosporidium nelsoni, Bonamia ostreae, and Minchinia tapetis (Fig. 4). The probe hybridized well with plasmodia and uninucleate cells of the haplosporidian in $P$. vannamei (Fig. 4d-f). Most notable is that the probe did not hybridize with any of the other haplosporidian species tested. The $B$. ostreae SSU rDNA sequence was most similar in overall pairwise genetic distance analyses $(p=0.152)$ to that of the $P$. vannamei parasite.
In addition, among the currently available haplosporidian sequences, the $H$. nelsoni and $M$. tapetis sequences were most similar to that of the $P$. vannamei parasite at the probe target site and the probe did not hybridize with either parasite species.

\section{DISCUSSION}

The haplosporidian infection detected in Belizean Penaeus vannamei was limited to the digestive gland or hepatopancreas, where all epithelial cell types appeared to be susceptible to infection. No acute host immune response was evident, even in severely infected HP tubules. However, some of the hepatopancreas did show foci of hemocyte encapsulated and melanized tubules that may have been similar to what Dyková et al. (1988) referred to as granulomatous lesions in Nicaraguan $P$. vannamei infected by a similar haplosporidian.

Even though Dyková et al. (1988) did not have the opportunity to perform a molecular study of the parasite, the pathology is similar. The similarities include target organ, presence of multinucleated plasmodia, uninucleated trophonts, plasmodium fragmentation and release of unicellular stages into the HP tubule lumen. In addition to these similarities, the closeness in geographical location strongly suggest that the parasite we found in Belize could be the same as that reported by Dyková et al. (1988), or at least a very closely related species. In both cases, no spores were observed, which makes it difficult to determine whether they belong to the same haplosporidian group or not. The same intracellular stages described by Dyková et al. (1988) were clearly visible in our samples.

The severity of the lesions found in some of the Belizean shrimp also indicate that the normal functions of the digestive gland are likely to be compromised, which could have resulted in clinical signs such as slow growth and, perhaps, low survival rates in these pondreared shrimp. Our finding of this parasite in pondreared shrimp was not the result of a systematic sampling scheme, and hence no information is available as to how prevalent the condition may have been at the farms. Additionally, the actual effect on pond production may be difficult to estimate because apparently there are no signs specific to this disease and because secondary infections, such as vibriosis, may compound the problem. 


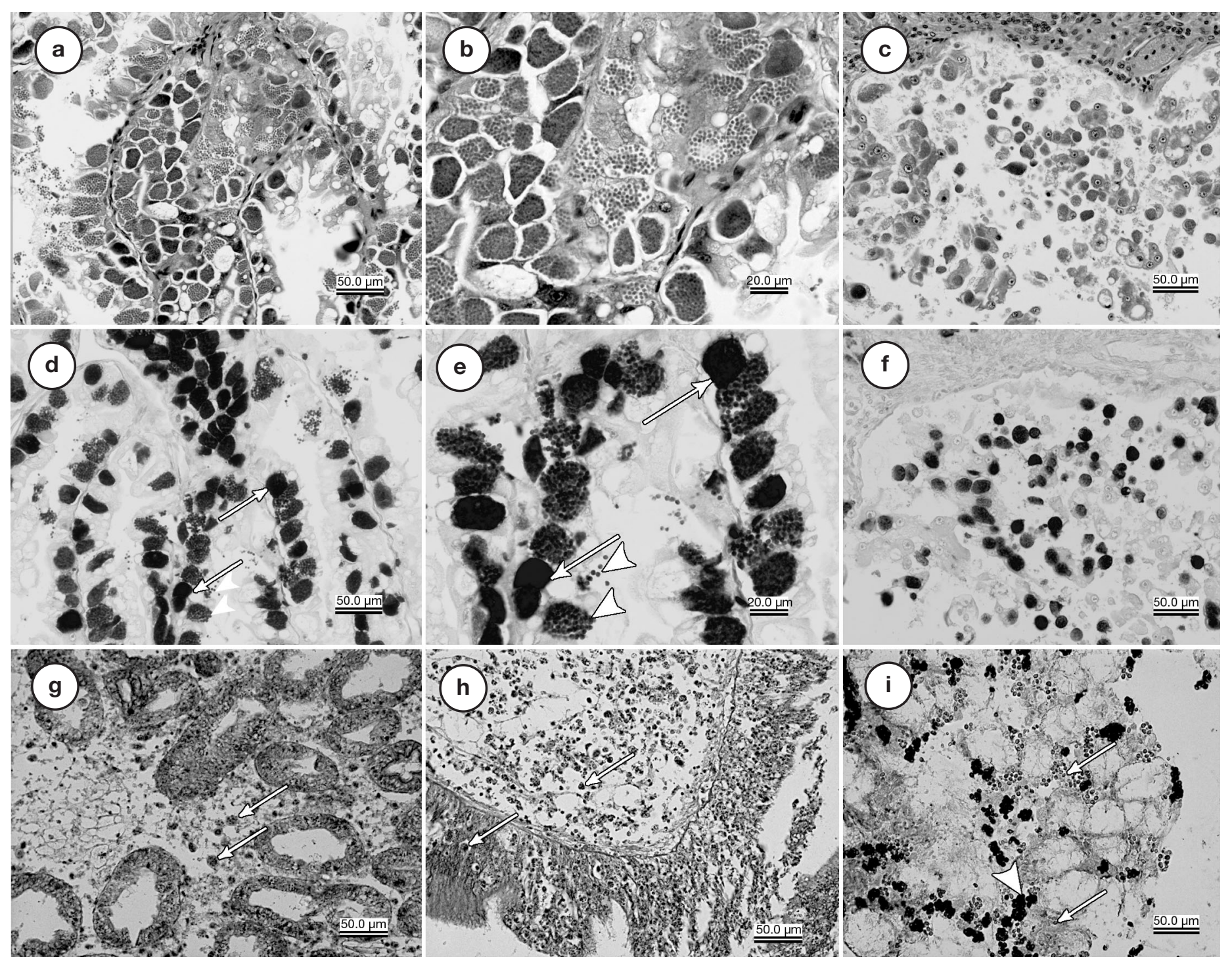

Fig. 4. Tissue sections of haplosporidian-infected hosts, demonstrating specificity of in situ hybridization (ISH) assay for parasite in Penaeus vannamei. (a-c) H\&E stain; (d-i) ISH with DNA probe BeShHap450. Micrographs of samples treated with both H\&E and ISH were close (not consecutive) sections. (a,d) shrimp in (a) at $200 \times$ magnification; (b,e) shrimp in (a) at 400 $\times$, showing plasmodia (arrows) and uninucleate stage cells (arrowheads); (c,f) shrimp in (b) at 200 $\times_{i}(\mathrm{~g}-\mathrm{i})$ other haplosporidians (arrows indicate plasmodia), all at 200 $\times_{i}(\mathrm{~g})$ Haplosporidium nelsoni in oyster Crassostrea virginica; (h) Bonamia ostreae in oyster Ostrea edulis; (i) Minchinia tapetis in carpet shell clam Venerupis philippinarum with spores (arrowhead) visible and counterstained

The haplosporidian infection does not appear to be a major threat to shrimp culture in this region. If this is in fact a re-emerged parasite, the last time infection was documented was in 1988 by Dyková et al. The shrimp stocks that originally became infected with the haplosporidian (described by Dyková et al. 1988) originated in Nicaragua; although the parasite was not observed until those stocks were shipped to Cuba. Enzootic presence or introduction via transfer of infected Penaeus vannamei stocks are 2 plausible explanations for the re-emergence of the disease. The parasite was possibly always present and enzootic in a crustacean or decapod in the Caribbean, and a combination of environ- mental and culturing conditions were optimal for the parasite to become established in cultured stocks. Additionally, movement of shrimp stocks throughout Mexico and Central America may have introduced the parasite from the Pacific side or other Central American countries where $P$. vannamei is native.

Although there is clearly strong support for placing this parasite into the phylum Haplosporidia based on morphology and the molecular phylogenetic analyses of the SSU rRNA gene sequence, the species cannot be placed in any of the existing genera with the data currently available. The molecular phylogeny suggests that this may be a representative of a new genus within 
the phylum. In addition, this analysis, as well as other recent haplosporidian phylogenic analyses (Reece et al. 2004, Burreson \& Reece 2006), indicate paraphyly of the genus Haplosporidium. As previously discussed, based on the molecular data (Burreson \& Reece 2006), it is likely that new genera will need to be designated within the Haplosporidia for placement of some Haplosporidium species, including $H$. nelsoni and $H$. louisiana, which fall outside the monophyletic clade that includes most Haplosporidium species. Unfortunately, the type species for the genus, $H$. scolopli, is not currently available for molecular analyses and defining this genus. Alternatively, the genera Bonamia, Minchinia and Haplosporidium should be synonymized into a single genus, although this option is less satisfying given the distinguishing features that can be attributed to the different genera (see Reece et al. 2004, and Burreson \& Reece 2006 for additional discussion of this issue). The phylogenetic analyses done for this study placed this parasite sister to the Bonamia/Minchinia clade within a larger clade that was sister to the clade containing most of the Haplosporidium species. This result suggests that either the Penaeus vannamei parasite represents yet another distinct genus within the phylum or should be placed into the synonymized genus. Additional morphological and molecular data from the known taxa within the phylum, as well as from new taxa as they are discovered, may help resolve the confusion surrounding the current generic designations in the phylum Haplosporidia.

Acknowledgements. Funding for this research was provided by a grant from the USMSFP, USDA, CSREES, Grant No. 2004-38808-02142. The authors thank Rita Redman for assistance in histological sectioning. We are also grateful to Silvia Rodriguez for supplying preserved samples and information on gross signs of haplosporidian infection. VIMS Contribution Number 2775 .

\section{LITERATURE CITED}

Altschul SF, Gish W, Miller W, Myers EW, Lipman DJ (1990) Basic local alignment search tool. J Mol Biol 215:403-410

Andrews JD (1966) Oyster mortality studies in Virginia. V. Epizootiology of MSX, a protistan pathogen of oysters. Ecology 47:19-31

Andrews JD, Wood JL, Hoese HD (1962) Oyster mortality studies in Virginia. III. Epizootiology of a disease caused by Haplosporidium costale Wood and Andrews. J Insect Pathol 4:1327-1343

Armstrong DA, Armstrong JL (1974) A haplosporidian infection in gaper clams, Tresus capax (Gould), from Yaquina Bay, Oregon. Proc Natl Shellfish Assoc 64:68-72

Barrow JH (1961) Observations of a haplosporidian, Haplosporidium pickfordi sp. nov. in freshwater snails. Trans Am Microsc Soc 80:319-329
Bell TA, Lightner DV (1988) A handbook of normal penaeid shrimp histology. World Aquaculture Society, Baton Rouge, LA

Bonami JR, Vivares CP, Brehelin M (1985) A new haplosporean parasite of the flat oyster, Ostrea edulis: morphology and cytology of the different stages. Protistologica 21:161-173

Bower SM, Meyer GR (2002) Morphology and ultrastructure of a protistan pathogen in the haemolymph of shrimp (Pandalus spp.) in the northeastern Pacific Ocean. Can J Zool 80:1055-1068

Burreson EM (2001) Spore ornamentation of Haplosporidium pickfordi Barrow, 1961 (Haplosporidia), a parasite of freshwater snails in Michigan, USA. J Eukaryot Microbiol 48:622-626

Burreson EM, Ford SE (2004) A review of recent information on the Haplosporidia, with special reference to Haplosporidium nelsoni (MSX disease). Aquat Living Resour 17: 499-517

Burreson EM, Reece KS (2006) Spore ornamentation of Haplosporidium nelsoni and Haplosporidium costale (Haplosporidia), and incongruence of molecular phylogeny and spore ornamentation in the Haplosporidia. J Parasitol 92:1295-1301

Burreson EM, Stokes NA, Carnegie RB, Bishop MJ (2004) Bonamia sp. (Haplosporidia) found in nonnative oysters Crassostrea ariakensis in Bogue Sound, North Carolina. J Aquat Anim Health 16:1-9

Diggles BK, Nichol J, Hine PM, Wakefield S, CochennecLaureau N, Roberts RD, Friedman CS (2002) Pathology of cultured paua Haliotis iris infected with a novel haplosporidian parasite, with some observations on the course of disease. Dis Aquat Org 50:219-231

Dyková I, Lom J, Fajer E (1988) A new haplosporean infecting the hepatopancreas in the penaeid shrimp, Penaeus vannamei. J Fish Dis 11:15-22

Hine PM, Cochennec-Laureau N, Berthe FCJ (2001) Bonamia exitiosus n. sp. (Haplosporidia) infecting flat oysters Ostrea chilensis in New Zealand. Dis Aquat Org 47:63-72

Holthuis LB (1980) FAO species catalog, Vol 1. Shrimp and prawns of the world. FAO Fish Synop 125:46

Lightner DV (1996) A handbook of shrimp pathology and diagnostic procedures for diseases of cultured penaeid shrimp. World Aquaculture Society, Baton Rouge, LA

Maniatis T, Fritsch EF, Sambrook J (1982) Molecular cloning: a laboratory manual. Cold Spring Harbor Laboratory, Cold Spring Harbor, NY

Medlin L, Elwood HJ, Stickel S, Sogin ML (1988) The characterization of enzymatically amplified eukaryotic 16S-like rRNA-coding regions. Gene 71:491-499

Meyers TR, Lightner DV, Redman RM (1994) A dinoflagellate-like parasite in Alaskan spot shrimp Pandalus platyceros and pink shrimp $P$. borealis. Dis Aquat Org 18:71-76

Novoa B, Balseiro P, Figueras A (2004) Molecular detection of a haplosporidian parasite in carpet shell clam Ruditapes decussatus from Spain. Dis Aquat Org 61:89-93

Perkins FO (1975) Fine structure of Minchinia sp. (Haplosporida) sporulation in the mud crab, Panopeus herbstii. Mar Fish Rev 37:46-60

Reece KS, Stokes NA (2003) Molecular analysis of a haplosporidian parasite from cultured New Zealand abalone Haliotis iris. Dis Aquat Org 53:61-66

Reece KS, Burreson EM, Bower SM, Dungan CF (2000) Molecular analyses of a parasite in prawns (Pandalus platyceros) from British Columbia, Canada. J Shellfish Res 19:647

Reece KS, Siddall ME, Stokes NA, Burreson EM (2004) Molecular phylogeny of the phylum Haplosporidia based 
on two independent gene sequences. J Parasitol 90: $1111-1122$

Rosenfield A, Buchanan L, Chapman GB (1969) Comparison of the fine structure of spores of three species of Minchinia (Haplosporida, Haplosporidiidae). J Parasitol 55:921-941

Stokes NA, Burreson EM (1995) A sensitive and specific DNA probe for the oyster pathogen Haplosporidium nelsoni. J Eukaryot Microbiol 42:350-357

Stokes NA, Burreson EM (2001) Differential diagnosis of mixed Haplosporidium costale and Haplosporidium nelsoni infections in the eastern oyster, Crassostrea virginica, using DNA probes. J Shellfish Res 20:207-213

Editorial responsibility: Timothy Flegel, Bangkok, Thailand
Swofford DL (2002) PAUP*: Phylogenetic analysis using parsimony ( ${ }^{*}$ and other methods), version 10. Sinauer Associates, Sunderland, MA

Thompson JD, Higgins DG, Gibson TJ (1994) Improving the sensitivity of progressive multiple sequence alignment through sequence weighing, position-specific gap penalties and weight matrix choice. Nucleic Acids Res 22:4673-4680

Zuker M, Mathews DH, Turner DH (1999) Algorithms and thermodynamics for RNA secondary structure prediction: In: Barciszewski J, Clark BFC (eds) A practical guide in RNA biochemistry and biotechnology. Kluwer Academic Publishers, Dordrecht, p 11-44

Submitted: July 19, 2006; Accepted: September 29, 2006 Proofs received from author(s): February 7, 2007 